A RCHIWA, BIBLIOTEKI

I MUZEA KOŚCIELNE 111 (2019)

https://doi.org.10.31743/abmk.2019.111.05

\author{
KS. JACEK KAPUŚCIŃSKI* - CZĘSTOCHOWA
}

\title{
OSIĄGNIĘCIA HISTORIOGRAFICZNE KSIĘŻY DIECEZJI CZESTOCHOWSKIEJ NA LAMACH PRASY PARAFIALNEJ W OKRESIE II RZECZYPOSPOLITEJ
}

\begin{abstract}
Streszczenie
Utworzona 28 października 1925 r. diecezja częstochowska swój rozwój zawdzięcza pierwszemu ordynariuszowi, którym był bp Teodor Kubina. Z jego inicjatywy już w 1926 r. został powołany do życia tygodnik diecezjalny „Niedziela”, wokół którego stopniowo rozwijał się ruch wydawniczy, powodując m.in. pojawienie się prasy parafialnej. Były to periodyki wydawane z różną częstotliwością (dwumiesięczniki, miesięczniki, dwutygodniki i tygodniki). Do 1939 r. ukazały się drukiem dwa tytuły czasopism ponadparafialnych i dziesięć tytułów czasopism parafialnych. Na ich łamach szczególną aktywność wydawniczą wykazywali miejscowi duchowni, którzy publikowali teksty o różnorodnej tematyce. Niezwykle interesujące wydają się być ich artykuły historyczne. W wyniku badań naukowych udało się ustalić aż 26 takich opracowań autorstwa ks. Teofila Jankowskiego (10 artykułów), ks. Władysława Macha (1 artykuł), ks. Stefana Niedźwiedzkiego (2 artykuły), ks. Tadeusza Peche (2 artykuły) i ks. Leona Stasińskiego (11 artykułów). Problematykę, którą w nich poruszali, można generalnie sprowadzić do dwóch bloków zagadnieniowych: kościelnych (24 artykuły) i pozakościelnych (2 artykuły). Pierwszy $\mathrm{z}$ nich poruszał wątki zawiązane $\mathrm{z}$ administracją kościelną, duszpasterstwem, dziejami parafii i biografistyką. Drugi natomiast dotyczył kwestii społecznych i patriotycznych. Pomimo, że wszystkie artykuły miały charakter popularnonaukowy bądź popularny, to jednak należy podkreślić wysoką jakość warsztatową prac ks. Leona Stasińskiego z Będzina, które były pisane na podstawie źródeł archiwalnych i ukazywały się w odcinkach.
\end{abstract}

Słowa kluczowe: czasopismo parafialne; diecezja częstochowska; duchowieństwo; parafia

\footnotetext{
* Ks. Jacek Kapuściński - dr historii; mgr-lic. teologii; dyrektor Archiwum Archidiecezji Częstochowskiej im. ks. Walentego Patykiewiczaw Częstochowie; e-mail: jacke3@o2.pl

https://orcid.org/0000-0003-0055-4356
} 
Dnia 28 października 1925 r. w strukturach Kościoła polskiego została utworzona diecezja częstochowska ze stolicą biskupią w Częstochowie. Na jej pierwszego ordynariusza papież Pius XI wyznaczył ks. Teodora Kubinę z Katowic, który urząd biskupi objął 2 lutego 1926 r. ${ }^{1}$. Od tego czasu w nowopowstałej diecezji nastąpił widoczny rozwój inicjatyw duszpasterskich, angażujących w życie religijne szerokie grono przedstawicieli wielu środowisk społecznych. Jedną z nich była koncepcja założenia tygodnika diecezjalnego „Niedziela”, którego pierwszy numer ukazał się 4 kwietnia 1926 r. $^{2}$. Czasopismo to - jak przyznał sam bp T. Kubina

chce [...] zawitać do każdego domu katolickiego, do każdego mieszkania, do każdej rodziny. Chce mówić [...] o Bogu, Najświętszej Maryi Pannie, o naszym Św. Kościele katolickim, o naszych świątyniach i uroczystościach, o życiu w naszych parafiach, o pięknych naszych katolickich zwyczajach i obyczajach, podstawach i zasadach naszej wiary. Chce nas łączyć w tej nowej diecezji częstochowskiej w jedną wielką rodzinę $[\ldots]^{3}$.

Jeszcze w 1926 r. Redakcja „Niedzieli” rozszerzyła ofertę wydawniczą o bezpłatny dodatek zatytułowany „Młodzież Katolicka”, wydawany z czasem jako miesięcznik, a później jako dwutygodnik. Prawdopodobnie w jego ramach w 1928 r. ukazały się tytuły: „II Sprawozdanie Związku Młodzieży Polskiej Żeńskiej w Częstochowie za rok 1927” i „II Sprawozdanie Związku Młodzieży Polskiej Męskiej w Częstochowie za rok 1927”. Także od 1928 r. Redakcja „Niedzieli” wprowadziła na rynek wydawniczy „Kalendarz Jasnogórski”, wydawany w formie książkowej na poszczególne lata ${ }^{4}$. Zainicjowany w ten sposób w diecezji ruch wydawniczy zataczał coraz szersze kręgi, inspirując niektórych duchownych do redagowania czasopism w parafiach. W takich okolicznościach powstały nowe tytuły prasowe, mające zasięg ponadparafialny i parafialny. Według zamysłu wydawców czasopisma te nie tylko realizowały misję edukacyjną czy informacyjną, ale przede wszystkim docierając do konkretnych rodzin uwrażliwiały je na lokalne sprawy Kościoła. W wyniku podjętych badań naukowych udało się ustalić co najmniej 12 tytułów prasowych, wydawanych przez parafie na terenie diecezji częstochowskiej do 1939 r. Łamy tych czasopism szczególnie były otwarte dla piszących księży, którzy zamieszczali tam swoje artykuły o wielorakiej tematyce. Nad wyraz interesujące wydają się być publikowane tam prace historyczne, których identyfikacja i omówienie stanowi cel badań niniejszego opracowania.

${ }^{1}$ Pius XI, Ditionis Polonicae de nova dioecesium latini ritus circumscriptione «Vixdum Poloniae unistas», „Acta Apostolicae Sedis”, 17 (1925), s. 521-528; P. Stanko, Bulla «Vixdum Poloniae unista» z 28 października 1925 roku. Geneza-znaczenie - dzieje - edycja, Katowice 2015, s. 90-91; Tenże, Bulla «Vixdum Poloniae unista». Reprodukcje stron oryginatu bulli: tekst taciński - tlumaczenie na język polski, Katowice 2015, s. 28.

${ }^{2}$ J. Kapuściński, $Z$ «Niedzielą» na co dzień. Formacja spoteczno-religijna w latach 1926-1939, „Biuletyn Informacyjny Komisji Historycznej Polskiej Akademii Nauk Oddział Katowice”, 11 (2014) s. 14-15.

${ }^{3}$ T. Kubina, Arcypasterska zachęta, „Niedziela”, 1 (1926) nr 1, s. 2.

${ }^{4}$ J. Kapuściński, Publikacje księży diecezji częstochowskiej na łamach „,Kalendarza Jasnogórskiego” z lat 1929-1938, „Veritati et Caritati”, 8 (2017) s. 277-296. 


\section{Czasopisma parafialne}

Rozwój przedsięwzięć duszpasterskich w diecezji częstochowskiej w okresie międzywojennym XX w. spowodował, iż w niektórych parafiach pojawiła się idea wydawania pism kościelnych. Miały one przede wszystkim charakter pastoralny, stąd zamieszczane w nich informacje odnosiły się głównie do lokalnego życia religijnego (m.in. ogłoszenia parafialne, wykaz intencji mszalnych, sprawozdania z działalności parafii i opisy wydarzeń religijnych). Wiele miejsca poświęcano w nich na różnego rodzaju artykuły popularyzatorskie, które z jednej strony miały pogłębiać pobożność wśród miejscowych wiernych (m.in. tematyka homiletyczna, liturgiczna i moralna), a z drugiej strony zapoznać ich z aktualnymi osiągnięciami niektórych dyscyplin naukowych (m.in. tematyka biblijna, dogmatyczna, historyczna, prawna i społeczna) $)^{5}$.

Wydawanie czasopism parafialnych nie mogło odbywać się bez aprobaty miejscowych proboszczów. To oni często byli ich redaktorami lub wyrażali zgodę, aby to zadanie wykonywali inni duchowni, zazwyczaj wikariusze lub prefekci. Pod względem objętościowym pisma te nie były zbyt obszerne, ponieważ liczyły zaledwie od 2 do 8 stron. Poza tym ukazywały się z różną częstotliwością (dwumiesięczniki, miesięczniki, dwutygodniki i tygodniki) ${ }^{6}$. Zdecydowanie jednak przeważały tygodniki, które generalnie stanowiły lokalny dodatek do diecezjalnego tygodnika „Niedziela” i do „Przewodnika Katolickiego”. Z tego też powodu drukowano je w formacie wspomnianych czasopism $(22,5 \times 31,2 \mathrm{~cm} \mathrm{i} 23 \times 30 \mathrm{~cm})^{7}$. Dodać trzeba, iż nakład takiej prasy parafialnej był dość zróżnicowany i oscylował pomiędzy 300 a 2.500 egzemplarzy .

Ogólnie czasopisma parafialne można podzielić na dwie grupy, odpowiadające zasięgowi terytorialnemu ich oddziaływania. W pierwszej kolejności należy wymienić te tytuły, które były adresowane do czytelników pochodzących jednocześnie z kilku parafii (czasopisma ponadparafialne). Wydawano je w ośrodkach miejskich, a więc tam, gdzie liczba ludności była dość wysoka i panowały podobne warunki egzystencjalne. Drugą zaś grupę stanowiły pisma li tylko przeznaczone dla czytelników należących do jednej parafii (czasopisma parafialne).

${ }^{5}$ Bibliografia katolickich czasopism religijnych $w$ Polsce 1918-1944, red. Z. Zieliński, Lublin 1981, ss. 69, 109-110, 114, 165-166, 328-333, 337, 356; Pierwsze pismo parafialne $w$ diecezji czestochowskiej, „Niedziela”, 4 (1929) nr 14, s. 171; Nowe pismo parafialne, „Niedziela”, 9 (1934) $\mathrm{nr} 3$, s. 34; Nowe pismo parafialne w naszej diecezji, „Niedziela”, 10 (1935) nr 47, s. 568.

${ }^{6}$ Bibliografia katolickich czasopism, ss. 69, 109-110, 114, 165-166, 328-333, 337, 356.

${ }^{7}$ J. Związek, Dzieje diecezji częstochowskiej w okresie II Rzeczypospolitej, Częstochowa 1990, s. 311; A. Bajor, Tygodnik katolicki „Niedziela” 1926-1939, „Rocznik Historii Prasy Polskiej”, 3 (2000) z. 2/6, s. 113; A. Bajor, Z. Żmigrodzki, Tygodnik katolicki „Niedziela” 1926-1939, Częstochowa 2002, ss. 95-96, 103.

${ }^{8}$ Bibliografia katolickich czasopism, ss. 69, 109-110, 114, 165-166, 328-333, 337, 356. 
Tabela 1. Czasopisma wydawane dla kilku parafii na terenie diecezji częstochowskiej do 1939 r.

\begin{tabular}{|c|c|c|c|c|}
\hline Lp. & Czasopismo & Parafie & Redaktor & $\begin{array}{c}\text { Okres } \\
\text { wydawania }\end{array}$ \\
\hline 1. & $\begin{array}{l}\text { Częstochowskie } \\
\text { Wiadomości } \\
\text { Parafialne }\end{array}$ & $\begin{array}{l}\text { 1. Świętej Rodziny w Częstochowie } \\
\text { 2. Św. Zygmunta w Częstochowie } \\
\text { 3. Św. Barbary w Częstochowie } \\
\text { 4. Św. Rocha w Częstochowie } \\
\text { 5. Opieki św. Józefa w Częstochowie }\end{array}$ & $\begin{array}{l}\text { Józef } \\
\text { Patrzyk }\end{array}$ & 1930 \\
\hline 2. & $\begin{array}{l}\text { Wiadomości } \\
\text { Parafialne }\end{array}$ & $\begin{array}{l}\text { 1. Św. Tomasza w Sosnowcu [Pogoń] } \\
\text { 2. Św. Barbary w Sosnowcu } \\
\text { [Stary Sielec] } \\
\text { 3. Niepokalanego Poczęcia NMP } \\
\text { w Sosnowcu [Nowy Sielec] }\end{array}$ & $\begin{array}{c}\text { Adam } \\
\text { Hendrychowski }\end{array}$ & 1933-1934 \\
\hline
\end{tabular}

Źródło: Bibliografia katolickich czasopism, ss. 69, 331-332; Częstochowskie Wiadomości Parafialne, „Niedziela”, 4 (1929) $\mathrm{nr}$ 48, s. 575.

Z podanych w tabeli danych wynika, iż w okresie międzywojennym w parafiach na terenie diecezji częstochowskiej wydano tylko dwa tytuły prasowe, których adresatami byli mieszkańcy więcej niż jednej parafii. Pierwsze takie czasopismo pojawiło się w Częstochowie i wydawano je pod nazwą „Częstochowskie Wiadomości Parafialne". Był to tygodnik, skierowany do wiernych należących do pięciu parafii częstochowskich ${ }^{9}$. Redakcją jego zajmował się wikariusz parafii św. Zygmunta w Częstochowie, który jednocześnie był w diecezji asystentem kościelnym Stowarzyszenia Robotników Chrześcijańskich ${ }^{10}$. Ogółem ukazało się jedynie 17 numerów tego pisma. Wydawano go w formie dodatku do „Niedzieli” w okresie od 2 marca do 29 czerwca 1930 r. ${ }^{11}$. Drugie czasopismo o zasięgu ponadparafialnym, opatrzone tytułem „Wiadomości Parafialne”, drukowano w Sosnowcu i miało postać miesięcznika, przeznaczonego dla czytelników z obszaru trzech parafii. Redaktorem jego był proboszcz parafii Niepokalanego Poczęcia NMP w Sosnowcu, który zdołał jedynie wydać 6 numerów tego pisma (grudzień 1933maj 1934). Co ciekawe, periodyk ten powstał na bazie wcześniej rozpowszechnianego w parafii Niepokalanego Poczęcia NMP w Sosnowcu pisma kościelnego,

9 T. Mielczarek, Od „Monitora” do „,Gońca Reklamowego”. Dzieje prasy częstochowskiej (1769-1994), Kielce 1996, s. 105. W publikacji tej autor stwierdził, iż „Częstochowskie Wiadomości Parafialne" były tygodnikiem parafii św. Zygmunta w Częstochowie, co nie jest zgodne z faktami, gdyż pismo to było tygodnikiem pięciu parafii częstochowskich.

${ }^{10}$ B. Snoch, Mała encyklopedia Częstochowy, Częstochowa 2002, s. 130; J. Sętowski, Cmentarz Kule w Częstochowie. Przewodnik biograficzny, Częstochowa 2005, s. 229; J. Kapuściński, Aktywność społeczno-kulturalna duchowieństwa diecezji częstochowskiej (do 1939 r.), w: ŚlaskPolska - Europa - Świat. Pamięci Profesora Jana Przewłockiego, red. K. Miroszewski, M. Stolarczyk, Katowice 2013, s. 98.

${ }^{11}$ W Bibliografia katolickich czasopism religijnych w Polsce 1918-1944 na s. 69 Z. Zieliński, opisując to czasopismo, zamieścił znak zapytania przy określeniu numeru 17 jako ostatniego, mając pewne wątpliwości, czy rzeczywiście był to ostatni numer periodyku. Otóż należy rozwiać tę wątpliwość, ponieważ udało się dotrzeć do numeru 17 tego pisma, z którego wynika, iż faktycznie był to numer ostatni. 
noszącego nawet ten sam tytuł („Wiadomości Parafialne”) i redagowanego przez tę samą osobę duchowną (ks. Adam Hendrychowski). Widocznie rozszerzenie zasięgu oddziaływania czasopisma nie przyniosło zamierzonych rezultatów, toteż po półrocznym eksperymencie zrezygnowano z przyjętego rozwiązania i powrócono do wcześniejszej koncepcji, adresując pismo do czytelników pochodzących $\mathrm{z}$ terenu jednej parafii ${ }^{12}$.

Tabela 2. Czasopisma poszczególnych parafii diecezji częstochowskiej w okresie II Rzeczypospolitej

\begin{tabular}{|c|c|c|c|c|}
\hline Lp. & Czasopismo & Parafia & Redaktor & $\begin{array}{c}\text { Okres } \\
\text { wydawania }\end{array}$ \\
\hline 1 & 2 & 3 & 4 & 5 \\
\hline 1. & Dodatek Parafialny & $\begin{array}{l}\text { Wniebowzięcia NMP } \\
\text { w Sosnowcu }\end{array}$ & Teofil Jankowski & 1934-1939 \\
\hline 2. & $\begin{array}{l}\text { Głos Duszpasterza, } \\
\text { przemianowany od R. } 1 \\
\text { [nr 36] na Dodatek } \\
\text { Parafialny }\end{array}$ & $\begin{array}{l}\text { Matki Boskiej Anielskiej } \\
\text { w Dąbrowie Górniczej }\end{array}$ & $\begin{array}{l}\text { Stefan } \\
\text { Niedźwiedzki }\end{array}$ & 1934-1939 \\
\hline \multirow{2}{*}{3.} & \multirow{2}{*}{ Głos Parafialny } & \multirow{2}{*}{$\begin{array}{l}\text { Świętej Rodziny } \\
\text { w Częstochowie }\end{array}$} & Stanisław Kuraś & 1933-1937 \\
\hline & & & {$[?]$} & $1937-1939$ \\
\hline \multirow{2}{*}{4.} & \multirow{2}{*}{ Kronika Parafialna ${ }^{a}$} & \multirow{2}{*}{ Św. Barbary w Porąbce } & $\begin{array}{l}\text { Józef } \\
\text { Krzyżanowski }\end{array}$ & $1928-1935$ \\
\hline & & & $\begin{array}{l}\text { Stanisław } \\
\text { Grzywak }\end{array}$ & $1935-1937$ \\
\hline
\end{tabular}

${ }^{a}$ W Bibliografia katolickich czasopism religijnych w Polsce 1918-1944 na s. 165-166 Z. Zieliński wymienił „Kronikę Parafialną” jako pismo parafii Porąbka i jako pismo osobno wychodzące dla dzielnicy Kazimierz k. Strzemieszyc. Tymczasem dzielnica ta wówczas wchodziła w skład parafii Porąbka. Nie udało się bowiem odnaleźć żadnych numerów czasopisma adresowanego dla mieszkańców dzielnicy Kazimierz k. Strzemieszyc, z czym także spotkał się Z. Zieliński ponieważ w opisie pisma nadmienił: „Nie odnaleziono”. Milczy też na ten temat kronika parafii, którą spisywał proboszcz ks. Józef Krzyżanowski, a obecnie przechowywana jest w miejscowym archiwum parafialnym. $Z$ treści tej kroniki wynika, że wychodziło tylko jedno czasopismo dla całej parafii Porąbka. Ponadto Z. Zieliński, idąc za sugestią „Pierwszego Polskiego Spisu Gazet i Czasopism”, wymienił jako redaktora pisma rozpowszechnianego w dzielnicy Kazimierz k. Strzemieszyc w latach 1938-1939 ks. Józefa Krzyżanowskiego, co jest wątpliwe, gdyż od 1935 r. był on już proboszczem w Przyrowie. Wydaje się zatem, że „Kronika Parafialna” była wyłącznie czasopismem adresowanym do wszystkich parafian, bez podziału na poszczególne dzielnice. Potwierdza to też opis ze stopki redakcyjnej pisma z 1936 r., gdzie przy wzmiance redaktora jest dopisek „Kazimierz k. Strzemieszyc". Być może tym zasugerowano się przy wyszczególnieniu owego tytułu prasowego w „Pierwszym Polskim Spisie Gazet i Czasopism”. Warto jeszcze dodać, że „Kronika Parafialna” w Porąbce wychodziła do 1937 r., tymczasem według „Pierwszego Polskiego Spisu Gazet i Czasopism" wymieniana jest jeszcze w latach 1938-1939, co albo jest błędem w datacji, albo rzeczywiście kontynuowano jej wydawanie w kolejnych latach. Zob. Archiwum Parafii Najświętszej Maryi Panny w Sosnowcu - Kazimierzu, sygn. brak, Kronika parafii, ss. 6, 9; J. Walicki, Ks. Józef Krzyżanowski, „Częstochowskie Wiadomości Diecezjalne”, 24-31 (1957) nr 3, s. 124.

${ }^{12}$ Bibliografia katolickich czasopism, s. 331-332. 


\begin{tabular}{|c|c|c|c|c|}
\hline 1 & 2 & 3 & 4 & 5 \\
\hline 5. & Wiadomości Parafialne & $\begin{array}{l}\text { Niepokalanego Poczęcia } \\
\text { NMP } \\
\text { w Sosnowcu [Nowy } \\
\text { Sielec] }\end{array}$ & $\begin{array}{l}\text { Adam } \\
\text { Hendrychowski }\end{array}$ & 1933-1934? \\
\hline 6. & Wiadomości Parafialne & $\begin{array}{l}\text { Św. Barbary w Sosnowcu } \\
\text { [Stary Sielec] }\end{array}$ & Władysław Mach & 1934-1939 \\
\hline 7. & Wiadomości Parafialne & Św. Joachima w Zagórzu & $\begin{array}{l}\text { Stanisław } \\
\text { Poroszewski }\end{array}$ & 1938-1939 \\
\hline 9. & Wiadomości Parafialne & $\begin{array}{l}\text { Św. Józefa } \\
\text { w Strzemieszycach }\end{array}$ & $\begin{array}{l}\text { Franciszek } \\
\text { Strugała }\end{array}$ & 1934-1935? \\
\hline 5. & Wiadomości Parafialne & $\begin{array}{l}\text { Św. Wawrzyńca } \\
\text { w Bobrownikach }\end{array}$ & $\begin{array}{l}\text { [Władysław } \\
\text { Marcinkowski] }\end{array}$ & $1930-1931$ \\
\hline \multirow{3}{*}{10.} & \multirow{3}{*}{ Życie Parafialne } & \multirow{3}{*}{$\begin{array}{l}\text { Przenajświętszej Trójcy } \\
\text { w Będzinie }\end{array}$} & Tadeusz Peche & $1935-1937$ \\
\hline & & & Leon Stasiński & 1937 \\
\hline & & & $\begin{array}{l}\text { Mieczysław } \\
\text { Zawadzki }\end{array}$ & $1937-1939$ \\
\hline
\end{tabular}

Źródło: Bibliografia katolickich czasopism, ss. 69, 109-110, 114, 165-166, 328, 330-333, 337, 356; Pierwsze pismo parafialne $w$ diecezji częstochowskiej, „Niedziela”, 4 (1929) nr 14, s. 171; Nowe pismo parafialne, „Niedziela”, 9 (1934) nr 3, s. 34; Nowe pismo parafialne w naszej diecezji, „Niedziela”, 10 (1935) nr 47, s. 568.

Prowadzona w diecezji częstochowskiej akcja wydawnicza czasopism parafialnych przypadła na lata 1928-1939. W tym okresie ukazało się drukiem aż 10 tytułów prasowych, które w powyższej tabeli zostały zestawione w porządku alfabetycznym ${ }^{13}$. Zawarta $\mathrm{w}$ nich treść poruszała zagadnienia związane przede wszystkim z życiem religijnym konkretnej parafii. Warto zwrócić uwagę, iż zdecydowaną większość czasopism wydawały parafie w Zagłębiu Dąbrowskim (9

${ }^{13}$ Tomasz Mielczarek w swojej książce pt. Od „,Monitora” do „,Gońca Reklamowego”. Dzieje prasy częstochowskiej (1769-1994) na s. 105 stwierdził: „W międzywojennej Częstochowie ukazywały się nie mniej niż trzy tego typu tytuły [czasopisma parafialne - J.K.]: «Częstochowskie Wiadomości Parafialne» [...], «Głos Parafialny» [...] oraz pismo redagowane przez proboszcza parafii NMP”. W przypisie do tego tekstu dodał, że „Pisma parafialne przechowywane są w Archiwum Archidiecezji Częstochowskiej”. Z całości więc wynika, jakoby miały być wydawane w Częstochowie trzy czasopisma parafialne, jednakże, o ile podał tytuły dwóch pierwszych periodyków, to w trzecim przypadku nie wymienił już nazwy pisma. Nie wspominają też o niej w swoich pracach naukowych ks. Jan Związek (Dzieje diecezji częstochowskiej w okresie II Rzeczypospolitej) i ks. Zygmunt Zieliński (Bibliografia katolickich czasopism religijnych w Polsce 1918-1944). Ponadto w wyniku kwerendy przeprowadzonej w Archiwum Archidiecezji Częstochowskiej w Częstochowie nie natrafiono na żaden egzemplarz takiego czasopisma. Natomiast, co ciekawe, odnaleziono numery czasopisma wydawanego przez parafię Wniebowzięcia NMP w Sosnowcu. Wszystko wskazuje więc na to, że T. Mielczarek pomylił miejscowości i zamiast Sosnowca wymienił Częstochowę. Za pomyłką tą przemawia jeszcze fakt, że w okresie międzywojennym nie było w Częstochowie żadnej „parafii NMP”. Zob. Katalog kościołów i duchowieństwa diecezji częstochowskiej 1939, Częstochowa 1939, s. 31-35. 
parafii), a tylko jedno czasopismo rozpowszechniano w Częstochowie (parafia katedralna). W redagowaniu tych periodyków uczestniczyło dwunastu duchownych znanych z imienia i nazwiska, o czym świadczą dane ze stopek redakcyjnych. Trudno natomiast wskazać jednoznacznie redaktora pisma wydawanego przez parafię Bobrowniki, niemniej, wykorzystując przesłankę, iż w tym czasie urzędował tam tylko proboszcz i był nim ks. Władysław Marcinkowski, można $z$ dużym prawdopodobieństwem przyjąć, że to on był redaktorem. Przemawiają za tym również dodatkowe argumenty: po pierwsze, prowadził on aktywność pisarską, bowiem na swoim koncie miał już publikację o dziejach parafii, w której poprzednio posługiwa ${ }^{14}$, a po drugie, czasopismo parafialne w Bobrownikach zaczęło być drukowane zaraz po objęciu przez niego urzędu proboszczowskiego ${ }^{15}$. Nie udało się natomiast ustalić personaliów redaktora czasopisma wydawanego w latach 1937-1939 przez parafię Świętej Rodziny w Częstochowie. O ile pracą tą wcześniej zajmował się ks. S. Kuraś, to w 1937 r. został on przeniesiony na inną placówkę kościelną i nie mógł dalej wykonywać tego zadania ${ }^{16} . \mathrm{Z}$ całą pewnością redaktorem tym musiał być miejscowy duchowny, stąd należy przyjąć, że ogółem redakcją czasopism parafialnych w diecezji częstochowskiej zajmowało się czternastu księży, spośród których co najmniej dziewięciu było proboszczami (Stanisław Grzywak, Adam Hendrychowski, Teofil Jankowski, Józef Krzyżanowski, Władysław Mach, [Władysław Marcinkowski], Stefan Niedźwiedzki, Tadeusz Peche i Mieczysław Zawadzki), a co najmniej pięciu wikariuszami (Stanisław Kuraś, Władysław Mach, Stanisław Poroszewski, Leon Stasińki i Franciszek Strugała). Jak można zauważyć, ks. Władysław Mach pojawił się i w grupie proboszczów i grupie wikariuszy, co rzecz jasna nie jest błędem, ponieważ swoją przygodę redaktorską zaczynał jako wikariusz, a kontynuował jako proboszcz. Warto nadmienić, iż w tych przypadkach, gdy redaktorem, bądź nawet wydawcą, był wikariusz, to i tak za całokształt wydawnictwa odpowiadał miejscowy proboszcz ${ }^{17}$.

\section{Stan liczebny publikacji historycznych $\mathrm{i}$ ich autorzy}

W celu wyłonienia artykułów o charakterze historycznym, których autorami byli duchowni diecezji częstochowskiej, należało przebadać zawartość treściową wspomnianych czasopism parafialnych. Na początku zatem przejrzano pod

${ }^{14}$ Archiwum Archidiecezji Częstochowskiej im. ks. Walentego Patykiewicza w Częstochowie (dalej: AACz), sygn. AP 119; J. Związek, Martyrologium kapłanów diecezji częstochowskiej w czasie II wojny światowej, „Częstochowskie Studia Teologiczne”, 4 (1976) s. 295; W. Marcinkowski, Historia parafji Przedmość, Częstochowa 1928.

${ }^{15}$ Ks. W. Marcinkowski był proboszczem w parafii Bobrowniki od 1929 r., zaś pierwsze numery miejscowego pisma parafialnego zaczęły się ukazywać w 1930 r. Zob. Związek, Martyrologium, s. 295 .

${ }^{16}$ J. Związek, Kuraś Stanisław (1887-1974), w: Stownik polskich teologów katolickich, t. 6, red. L. Grzebien, Warszawa 1983, s. 273-274.

${ }^{17} \mathrm{~W}$ ruch wydawniczy periodyków parafialnych, poza wspomnianymi wyżej duchownymi, było zaangażowanych także czterech proboszczów: ks. Mieczysław Rogójski (Strzemieszyce), ks. Stanisław Senko (Zagórze), ks. Jan Smużyński (Sosnowiec) i ks. Bolesław Wróblewski (Częstochowa). 
tym kątem periodyki o zasięgu ponadparafialnym („Częstochowskie Wiadomości Parafialne” i „Wiadomości Parafialne” [Sosnowiec - Pogoń, Stary Sielec, Nowy Sielec]), w wyniku czego stwierdzono, że w obydwóch przypadkach zachował się komplet numerów (17 egz. i 6 egz.), jednak nie odnaleziono w nich żadnych prac o tematyce historycznej ${ }^{18}$.

O wiele bardziej złożona okazała się kwerenda w pismach o zasięgu parafialnym. Natrafiono tutaj na podwójne trudności. Najpierw wyniknął problem w dotarciu do wszystkich drukowanych tytułów prasowych, ponieważ nie zachowały się żadne egzemplarze „Głosu Parafialnego”, wydawanego przez parafię katedralną w Częstochowie ${ }^{19}$. Poza tym, po zidentyfikowaniu pozostałych dziewięciu tytułów i ich przeanalizowaniu, wyszło na jaw, że występują braki niektórych numerów aż w sześciu czasopismach: „Dodatku Parafialnym” [Sosnowiec] ${ }^{20}$, „Głosie Duszpasterza”/,Dodatku Parafialnym” [Dąbrowa Górnicza $]^{21}$, „Kronice Parafialnej” [Porąbka] ${ }^{22}$, „Wiadomościach Parafialnych” [Sosnowiec - Stary Sielec $]^{23}$, „Wiadomościach Parafialnych” [Zagórze $]^{24}$ i „Wiadomościach Parafial-

18 „Częstochowskie Wiadomości Parafialne”, 1 (1930) nr 1-17; „Wiadomości Parafialne” [Pogoń, Stary Sielec, Nowy Sielec], 1 (1933) nr 3 - 2 (1934) nr 1-5.

${ }^{19} \mathrm{O}$ istnieniu tego czasopisma można dowiedzieć się z co najmniej czterech publikacji, których autorami są: ks. Zygmunt Zieliński (Bibliografia katolickich czasopism religijnych $w$ Polsce 1918-1944, s. 114), ks. Jan Związek (Dzieje diecezji częstochowskiej w okresie II Rzeczypospolitej, s. 311), Tomasz Mielczarek (Od „Monitora” do „, Gońca Reklamowego”. Dzieje prasy częstochowskiej «1769-1994», s. 105) oraz Agnieszka Bajor i Zbigniew Żmigrodzki (Tygodnik katolicki „Niedziela" 1926-1939, s 103). Z not dokumentacyjnych wszystkich tych prac wynika, że miejscem przechowywania owego periodyku było Archiwum Diecezjalne w Częstochowie, przemianowane w 1992 r. na Archiwum Archidiecezji Częstochowskiej. W tej sytuacji zdecydowano się przeszukać cały zasób tej instytucji, lecz nie udało się odnaleźć żadnego numeru tego czasopisma. Wspomniane publikacje, a szczególnie ks. Zygmunta Zielińskiego, dowodzą, że na jeden numer tego pisma natrafił ks. Jan Związek, kiedy pracował jako archiwariusz w Archiwum Diecezjalnym w Częstochowie. Po przeprowadzonej z nim rozmowie ustalono, że do 1991 r. ów jeden egzemplarz znajdował się w zasobie tegoż archiwum, lecz prawdopodobnie zaginął podczas przenoszenia materiałów archiwalnych do nowej siedziby tej instytucji (ul. Św. Barbary 41). Nie zachowało się to czasopismo w innych instytucjach naukowych, a także nie ma o nim żadnych śladów w Archiwum Parafii Archikatedralnej Świętej Rodziny w Częstochowie. Ponadto w 2017 r., z okazji 100-lecia parafii Świętej Rodziny, została otwarta w jednej z wież katedry częstochowskiej specjalna Izba Pamięci, w której zgromadzono wiele cennych pamiątek z dziejów miejscowej placówki kościelnej. Niektóre eksponaty pozyskano nawet z prywatnych zbiorów parafian, którzy przekazali je w odpowiedzi na apele duszpasterzy. Wśród zebranych pamiątek również nie znalazł się żaden egzemplarz „Głosu Parafialnego".

${ }^{20}$ Brak nr 1-4 z R. 1; nr 1-33, 41, 43 z R. 2; nr 1-2, 4-14, 30-31 z R. 3; nr 24 z R. 4 i nr 1, 33 z R. 6. Ponadto w Bibliografii katolickich czasopism religijnych w Polsce 1918-1944 Z. Zieliński podał, że być może ostatni numer tego czasopisma został wydany 30 lipca 1939 r. (s. 332-333). Tymczasem udało się jeszcze odnaleźć dalsze numery, z których ostatni nosi datę 20 sierpnia 1939 r. Nie wiadomo natomiast dlaczego autor umieścił opis tego periodyku pod nazwą „Wiadomości Parafialne”, skoro był on przez cały czas drukowany pod nazwą „Dodatek Parafialny”.

${ }^{21}$ Brak nr 1-2, 5-10, 14-15, 22, 25, 29, 35, 44 z R. 1; nr 45-46, 51 z R. 2; nr 1-52 z R. 5.

${ }^{22}$ Brak nr 18, 20 z R. 4; nr 1 z R. 10.

${ }^{23}$ Brak nr 2, 5-6- z R. 1; nr 14, 21-24 z R. 3; nr 30-33, 39-42 z R. 4; nr 15-16 z R. 6.

${ }^{24}$ Brak nr 6-12 z R. 1, nr 1-5 z R. 2. 
nych" [Bobrowniki] ${ }^{25}$. Nie udało się też jednoznacznie potwierdzić, czy 11 zachowanych numerów ,Wiadomości Parafialnych” z parafii św. Józefa w Strzemieszycach stanowi całość wydawnictwa ${ }^{26}$. W tej sytuacji tylko w dwóch przypadkach można mówić o istniejących do dzisiaj kompletach numerów pism parafialnych, a odnosi się to do ,Wiadomości Parafialnych” [Sosnowiec - Nowy Sielec] i „Życia Parafialnego" [Będzin].

W wyniku przeprowadzonej analizy treści zachowanych czasopism parafialnych ustalono, że na ich łamach zostało opublikowanych 26 artykułów historycznych, które wyszły spod piór księży diecezji częstochowskiej. Poniżej zamieszczono ich wykaz w porządku chronologicznym.

Tabela 3. Artykuły historyczne księży diecezji częstochowskiej na łamach czasopism parafialnych w okresie II Rzeczypospolitej

\begin{tabular}{|c|c|c|c|c|c|}
\hline Lp. & Autor & Tytul artykułu & Czasopismo & $\begin{array}{c}\text { Rok } \\
\text { i numer } \\
\text { wydania }\end{array}$ & $\begin{array}{l}\text { Liczba } \\
\text { stron }\end{array}$ \\
\hline 1 & 2 & 3 & 4 & 5 & 6 \\
\hline 1. & $\begin{array}{l}\text { [Stefan } \\
\text { Niedźwiedzki] }\end{array}$ & Co to jest parafia? & „Głos Duszpasterza” & $\begin{array}{c}1934 \mathrm{nr} \\
20\end{array}$ & 2 \\
\hline 2. & [Teofil Jankowski] & Historia oplatka & $\begin{array}{l}\text { „Dodatek Parafialny” } \\
\text { [Sosnowiec] }\end{array}$ & $\begin{array}{c}1934 \mathrm{nr} \\
44\end{array}$ & 1 \\
\hline 3. & $\begin{array}{l}\text { [Stefan } \\
\text { Niedźwiedzki] }\end{array}$ & \begin{tabular}{|l|} 
Życiorys śp. ks. prałata \\
Stanistawa Mazurkiewicza
\end{tabular} & $\begin{array}{l}\text { „Dodatek Parafialny” } \\
\text { [Dabrowa Górnicza] }\end{array}$ & $\begin{array}{c}1935 \mathrm{nr} \\
62\end{array}$ & 1 \\
\hline 4. & [Teofil Jankowski] & Św. Stanistaw Kostka & $\begin{array}{l}\text { „Dodatek Parafialny” } \\
\text { [Sosnowiec] }\end{array}$ & $\begin{array}{c}1935 \mathrm{nr} \\
46\end{array}$ & 2 \\
\hline 5. & \begin{tabular}{|l|} 
[Teofil \\
Jankowski]
\end{tabular} & Św. Cecylia & $\begin{array}{l}\text { „Dodatek Parafialny” } \\
\text { [Sosnowiec] }\end{array}$ & $\begin{array}{c}1935 \mathrm{nr} \\
47\end{array}$ & 2 \\
\hline 6. & $\mathrm{~T}[$ eofil] J[ankowski] & Wieczór Św. Sylwestra & $\begin{array}{l}\text { „Dodatek Parafialny” } \\
\text { [Sosnowiec] }\end{array}$ & $\begin{array}{c}1935 \mathrm{nr} \\
52\end{array}$ & 1 \\
\hline 7. & [Tadeusz Peche] & Czym jest diecezja? & „Życie Parafialne” & $\begin{array}{c}1936 \\
\mathrm{nr} 4\end{array}$ & 2 \\
\hline 8. & $\mathrm{~T}[$ eofil] J[ankowski] & $\begin{array}{l}\text { W pamiętna rocznice } \\
\text { bohaterskiej śmierci } \\
\text { ks. Ignacego Skorupki }\end{array}$ & $\begin{array}{l}\text { „Dodatek Parafialny” } \\
\text { [Sosnowiec] }\end{array}$ & $\begin{array}{c}1936 \mathrm{nr} \\
32\end{array}$ & 2 \\
\hline 9. & Tad[eusz] Peche & $\begin{array}{l}\text { Historia kredytu } \\
\text { bezprocentowego }\end{array}$ & „Życie Parafialne” & $\begin{array}{c}1936 \mathrm{nr} \\
33\end{array}$ & 1 \\
\hline 10. & [Władysław Mach] & Św. Franciszek z Asyżu & $\begin{array}{l}\text { „Wiadomości } \\
\text { Parafialne” [Stary } \\
\text { Sielec] }\end{array}$ & $\begin{array}{c}1936 \mathrm{nr} \\
36\end{array}$ & 1 \\
\hline 11. & [Teofil Jankowski] & Historia optatka & $\begin{array}{l}\text { „Dodatek Parafialny” } \\
\text { [Sosnowiec] }\end{array}$ & $\begin{array}{c}1936 \mathrm{nr} \\
48\end{array}$ & 1 \\
\hline
\end{tabular}

${ }^{25}$ Brak nr 2-4 z R. 2. W Bibliografii katolickich czasopism religijnych w Polsce 1918-1944 na s. 328-329 Z. Zieliński podał, że dotarł tylko do dwóch numerów tego czasopisma (nr 3-4 z 1930 r.), stąd nie udało mu się określić częstotliwości jego wydawania. Tymczasem odnaleziono kolejne numery z lat 1930-1931. Po ich przeanalizowaniu można uznać, że pismo to było dwumiesięcznikiem.

${ }^{26}$ Bibliografia katolickich czasopism, s. 337. 


\begin{tabular}{|c|c|c|c|c|c|}
\hline 1 & 2 & 3 & 4 & 5 & 6 \\
\hline 12. & $\mathrm{~T}[$ eofil] J[ankowski] & $\begin{array}{l}\text { Naród polski w hotdzie } \\
\text { NMP Niepokalanej }\end{array}$ & $\begin{array}{l}\text { „Dodatek Parafialny” } \\
\text { [Sosnowiec] }\end{array}$ & $\begin{array}{c}1936 \mathrm{nr} \\
49\end{array}$ & 2 \\
\hline 13. & [Leon Stasiński] & Jubileuszowa księga & „Życie Parafialne” & $\begin{array}{l}1937 \mathrm{nr} \\
14-15, \\
17-19\end{array}$ & 5 \\
\hline 14. & [Leon Stasiński] & $\begin{array}{l}\text { Poznaj swoja prastara } \\
\text { parafię }\end{array}$ & „Życie Parafialne” & $\begin{array}{c}1937 \\
\text { nr } 16- \\
31\end{array}$ & 20 \\
\hline 15. & $\mathrm{~T}[$ eofil] J[ankowski] & Majowe nabożeństwo & $\begin{array}{l}\text { „Dodatek Parafialny” } \\
\text { [Sosnowiec] }\end{array}$ & $\begin{array}{c}1937 \mathrm{nr} \\
19\end{array}$ & 1 \\
\hline 16. & $\mathrm{~L}$ [eon] S[tasiński] & $\begin{array}{l}\text { Ks. Tadeusz Peche. } \\
\text { Proboszcz parafii Będzin }\end{array}$ & „Życie Parafialne” & $\begin{array}{c}1937 \mathrm{nr} \\
32\end{array}$ & 2 \\
\hline 17. & $\mathrm{~T}[$ eofil] J[ankowski] & $\begin{array}{l}\text { W rocznicę Cudu nad } \\
\text { Wista }\end{array}$ & $\begin{array}{l}\text { „Dodatek Parafialny” } \\
\text { [Sosnowiec] }\end{array}$ & $\begin{array}{c}1937 \mathrm{nr} \\
33\end{array}$ & 2 \\
\hline 18. & L[eon] S[tasiński] & $\begin{array}{l}\text { Wzbudźmy tradycje } \\
\text { będzińskie }\end{array}$ & „Życie Parafialne” & $\begin{array}{c}1937 \mathrm{nr} \\
37,39, \\
43-50- \\
1938 \mathrm{nr} \\
1,5\end{array}$ & 14 \\
\hline 19. & $\mathrm{~L}[$ eon] $\mathrm{S}[$ tasiński] & $\begin{array}{l}\text { Rezurekcja w królewskim } \\
\text { swobodnem mieście } \\
\text { Bandzinie }\end{array}$ & „Życie Parafialne” & $\begin{array}{c}1938 \mathrm{nr} \\
16\end{array}$ & 2 \\
\hline 20. & $\mathrm{~L}[$ eon] S[tasiński] & Księża będzińscy & „Życie Parafialne” & $\begin{array}{l}1938 \mathrm{nr} \\
17-19 \\
22-25\end{array}$ & 7 \\
\hline 21. & $\mathrm{~L}[$ eon] S[tasiński] & $\begin{array}{l}\text { Kardynat-późniejszy } \\
\text { papież w Będzinie }\end{array}$ & „Życie Parafialne” & $\begin{array}{c}1938 \\
\mathrm{nr} 35 \\
37 \\
\end{array}$ & 2 \\
\hline 22. & $\mathrm{~L}$ [eon] S[tasiński] & Historia schodów & „Życie Parafialne” & $\begin{array}{c}1938 \mathrm{nr} \\
38\end{array}$ & 1 \\
\hline 23. & $\mathrm{~L}$ [eon] S[tasiński] & Z przeszlości Będzina & „Życie Parafialne” & $\begin{array}{c}1938 \mathrm{nr} \\
39-40, \\
42-45\end{array}$ & 8 \\
\hline 24. & T[eofil] J[ankowski] & $\begin{array}{l}\text { Naród polski w hotdzie } \\
\text { NMP Niepokalanej }\end{array}$ & $\begin{array}{l}\text { „Dodatek Parafialny” } \\
\text { [Sosnowiec] }\end{array}$ & $\begin{array}{c}1938 \mathrm{nr} \\
49\end{array}$ & 2 \\
\hline 25. & [Leon Stasiński] & \begin{tabular}{|l} 
Dokument Rady \\
Będzińskiej 1598 roku
\end{tabular} & „Życie Parafialne" & $\begin{array}{l}1939 \\
\text { nr } 2\end{array}$ & 2 \\
\hline 26. & L[eon] Stasiński & $\begin{array}{l}\text { Ze starych dokumentów } \\
\text { będzińskich }\end{array}$ & „Życie Parafialne” & $\begin{array}{l}1939 \mathrm{nr} \\
5-11 \\
13-20 \\
22\end{array}$ & 19 \\
\hline
\end{tabular}

Źródło: „Głos Duszpasterza”/,Dodatek Parafialny” [Dąbrowa Górnicza] 1934-1939; „Dodatek Parafialny” [Sosnowiec] 1934-1939; „Wiadomości Parafialne” [Sosnowiec - Stary Sielec] 19341939; „Życie Parafialne” 1935-1939. 
Z informacji zebranych w tabeli nr 3 wynika, że tylko w czterech czasopismach parafialnych były publikowane artykuły historyczne autorstwa miejscowego duchowieństwa („Głos Duszpasterza”/Dodatek Parafialny” [Dąbrowa Górnicza], „Dodatek Parafialny” [Sosnowiec], „Wiadomości Parafialne” [Sosnowiec - Stary Sielec] i „Życie Parafialne”). Wszystkie te periodyki - co należy podkreślić - ukazywały się w miastach Zagłębia Dąbrowskiego (Będzin, Dąbrowa Górnicza i Sosnowiec). Niektóre z 26 artykułów były in extenso przedrukami (Historia opłatka i Naród polski w hołdzie NMP Niepokalanej), inne zaś ukazywały w odcinkach (Jubileuszowa księga - 5 odcinków, Kardynat - późniejszy papież w Będzinie - 2 odcinki, Księża będzińscy - 7 odcinków, Poznaj swoja prastara parafie - 16 odcinków, Wzbudźmy tradycje będzińskie - 12 odcinków, $Z$ przeszłości Będzina - 5 odcinków i Ze starych dokumentów będzińskich - 16 odcinków). Dane tabelaryczne informują też, że problematyką historyczną zajmowało się pięciu księży: Teofil Jankowski (10 artykułów, w tym 2 przedruki), Władysław Mach (1 artykuł), Stefan Niedźwiedzki (2 artykuły), Tadeusz Peche (2 artykuły) i Leon Stasiński (11 artykułów). Biorąc pod uwagę, że do 1939 r. przez diecezję częstochowską przeszło 473 księży ${ }^{27}$, zatem niewiele ponad $1 \%$ $\mathrm{z}$ nich pisało $\mathrm{w}$ prasie parafialnej artykuły historyczne. Najwięcej napisał ich ks. L. Stasiński, który pod względem twórczości historycznej zdecydowanie górował nad pozostałymi, ponieważ w pracy swej wykorzystywał źródła archiwalne, jak również zamieszczał opracowania w odcinkach, co pozwoliło mu uchwycić szerszą perspektywę podejmowanego problemu.

\section{Problematyka opracowań historycznych}

Zakres tematyczny wspomnianych 26 artykułów popularnonaukowych był dość szeroki i zróżnicowany pod względem historycznym. Umownie można go bowiem sprowadzić do dwóch nurtów zagadnieniowych: kościelnych i pozakościelnych. Zwłaszcza w tym drugim przypadku poruszane kwestie mają wydźwięk niekonwencjonalny, zważywszy na to, że ich autorami byli duchowni. Biorąc jednak po uwagę problematykę kościelną trzeba stwierdzić, że sklasyfikować w niej można aż 24 artykuły. W celu ich usystematyzowania zostało zastosowane kryterium spektrum badawczego, co w konsekwencji wygenerowało następujący układ wątków: administracja kościelna, duszpasterstwo, dzieje parafii i biografistyka.

W odniesieniu do administracji kościelnej opublikowano 2 artykuły. Pierwszy z nich, zatytułowany Co to jest parafia?, ukazał się w „Głosie Duszpasterza” w 1934 r. Autorem jego był ks. Stefan Niedźwiedzki, redaktor wzmiankowanego pisma i proboszcz parafii pw. Matki Boskiej Anielskiej w Dąbrowie Górniczej. Kiedy pisał ten artykuł miał już 48 lat $^{28}$. Nie był to jednak jego debiut historiograficzny, ponieważ już 11 lat wcześniej opublikował na łamach „Kroniki Die-

${ }^{27}$ J. Kapuściński, Charakterystyka strukturalna kadr duchowieństwa diecezji częstochowskiej w latach 1925-1939, „Veritati et Caritati”, 4 (2015) s. 269.

28 J. Walicki, Śp. ks. Stefan Niedźwiedzki, „Częstochowskie Wiadomości Diecezjalne”, 34 (1960) nr 3, s. 114-116; T. Malarski, K. Franusiak, I. Mandrysz, Dzieje parafii św. Józefa-Częstochowa-Raków, Częstochowa [brw], s. 116-117. 
cezji Kujawsko-Kaliskiej” biogram jednego ze zmarłych księży ${ }^{29}$. Ponadto odkąd zainicjował wydawanie czasopisma parafialnego, to regularnie zamieszczał tam swoje artykuły z różnych dziedzin teologicznych. Ten o parafii był bowiem wykładnią, jak na przestrzeni dziejów kształtowała się funkcja tego rodzaju placówek kościelnych (czasy apostolskie, uchwały Soboru Trydenckiego, kanony Kodeksu Prawa Kanonicznego z 1917 r. i list pasterski kard. Augusta Hlonda ${ }^{30}$. Drugi artykuł natomiast, noszący tytuł Czym jest diecezja?, został opublikowany w „Życiu Parafialnym”. Napisał go w 1936 r. ks. Tadeusz Peche (ur. 1882 r.), będący redaktorem tegoż czasopisma i jednocześnie proboszczem będzińskim. Jeden z jego biografów zaznaczył, że był on „kapłanem światłym, o wysokiej kulturze osobistej". Miał też za sobą karierę kapelana wojskowego i prefekta szkolnego. Swój talent pisarski szczególnie rozwinął w dziedzinie wychowawczej, czego owocem był wydany przez niego podręcznik do nauczania w szkołach średnich pt. Pedagogika, który w okresie międzywojennym doczekał się aż dwóch wznowień wydawniczych ${ }^{31}$. Pisał też wiele artykułów do założonego przez siebie będzińskiego czasopisma parafialnego. Jeden z nich, poświęcony tematyce diecezji, opublikował z okazji dziesiątej rocznicy objęcia przez bp. Teodora Kubinę rządów w diecezji częstochowskiej. W pracy tej zaprezentował najpierw krótki opis procesów, w wyniku których doszło do powstania diecezji jako takiej $\mathrm{i}$ istniejących $\mathrm{w}$ jej ramach najważniejszych instytucji, a następnie przeniósł te ustalenia na grunt diecezji częstochowskiej, ukazując jej dziesięcioletnie dzieje. Całość wywodu zaś podsumował wzniosłą myślą pisząc: ,[...] diecezja nasza ze względu na zajmowaną ziemię jest częścią naszej ojczyzny. Cokolwiek czynimy dla diecezji, tym samym czynimy też dla Polski, jej rozwoju kulturalnego i materialnego, jej pięknej przyszłości i przeznaczenia"'32.

Nieco węższy zakres tematyczny przedstawiało kolejnych 5 artykułów, których treść dotyczyła kwestii duszpasterskich. Wszystkie te opracowania wyszły spod pióra ks. Teofila Jankowskiego (ur. 1877 r.) i zostały opublikowane na łamach założonego przez niego „Dodatku Parafialnego” w parafii Wniebowzięcia NMP w Sosnowcu. Warto dodać, że autor ten był w tej placówce proboszczem, znanym powszechnie z szerokiej działalności społecznej i patriotycznej ${ }^{33}$. Poza tym zajmował się również twórczością pisarską, publikując swoje utwory - w tym także historyczne - w różnych czasopismach ${ }^{34}$. We wspomnianym periodyku pa-

${ }^{29}$ J. Kapuściński, Bibliografia duchowieństwa diecezji częstochowskiej. Publikacje na lamach „,Kroniki Diecezji Kujawsko-Kaliskiej” w latach 1907-1925, „Studia Włocławskie”, 17 (2015) s. 534.

${ }^{30}$ [S. Niedźwiedzki], Co to jest parafia?, „Głos Duszpasterza”, 1 (1934) nr 20, s. 1-2.

${ }^{31}$ AACz, sygn. AP 157; W. P[atykiewicz], Ks. Tadeusz Peche (1882-1937), „Częstochowskie Wiadomości Diecezjalne”, 38 (1964) nr 7, s. 169; M. Trąba, Życie religijne w Będzinie (1918-1939), w: Będzin 1358-2008, t. 3, red. A. Glimos-Nadgórska, Będzin 2008, s. 441.

${ }^{32}$ [T. Peche], Czym jest diecezja?, „Życie Parafialne”, 2 (1936) nr 4, s. 1-2.

${ }^{33}$ AACz, sygn. AP 68, AP 331; W.P. Wlaźlak, Ks. Teofil Jankowski (28 II 1877-11 IV 1951), „Wiadomości Archidiecezji Częstochowskiej”, 80 (2006) nr 12, s. 74-75; G. Kośny, Mój umiłowany kościót. Monografia kościoła parafialnego pw. Św. Jana Chrzciciela w Brzeźnicy k. Radomska, Brzeźnica-Radomsko 2011, s. 34-36.

${ }^{34}$ J. Kapuściński, Bibliografia duchowieństwa, s. 534. 
rafialnym zadebiutował historiograficznie w 1934 r., kiedy to ukazał się jego artykuł pt. Historia opłatka (przedruk w tym samym czasopiśmie w 1936 r.). Nawiązując w nim najpierw do polskiej tradycji kolędowej, przedstawił następnie dzieje opłatka, sięgając w swoich rozważaniach aż do czasów pierwszych wieków chrześcijaństwa ${ }^{35}$. W kolejnym artykule, opatrzonym tytułem Naród polski $w$ hołdzie NMP Niepokalanej i wydanym w 1936 r. (przedruk w tym samym czasopiśmie w 1938 r.), opisał dzieje obchodów święta Niepokalanego Poczęcia NMP, począwszy od wieku VII aż po rok $1854^{36}$. Ostatni natomiast artykuł o tematyce duszpasterskiej został opublikowany w 1937 r. pt. Majowe nabożeństwo. Autor odtworzył w nim pokrótce etapy, jakie praktyka tego nabożeństwa przeszła, pokonując drogę od Rzymu (początek XIX w.) aż do Warszawy (poł. XIX w.), a następnie zrekapitulował to wszystko objaśnieniem współczesnej formy tego obrzędu ${ }^{37}$.

Wszystkie wspomniane wyżej opracowania historyczne zostały przebite pod względem warsztatowym przez artykuły o dziejach parafii będzińskiej autorstwa ks. Leona Stasińskiego. Ukazały się one w latach 1937-1939 w odcinkach na lamach ,Życia Parafialnego”, wydawanego przez parafię pw. Przenajświętszej Trójcy w Będzinie. Autor ich w tym czasie pełnił w miejscowej parafii obowiązki wikariusza, a także jako prefekt nauczał religii w szkołach. Zanim objął te funkcje (1935 r.) posługiwał duszpastersko w parafii sosnowieckiej na Starym Sielcu, gdzie m.in. wspierał pod względem wydawniczym tamtejsze pismo parafialne i publikował w nim swoje teksty ${ }^{38}$. Te doświadczenia następnie przeniósł na grunt będziński, zachęcając skutecznie miejscowego proboszcza do założenia podobnego czasopisma ${ }^{39}$. Od tego czasu związał się w będzińskim periodykiem parafialnym i drukował w nim liczne artykuły, potwierdzając tym samym, że opanował umiejętność sprawnego operowania piórem. Szczególnie cenne okazały się jego artykuły o przeszłości placówki kościelnej w Będzinie, które z czasem złożyły się na opracowaną przez niego pierwszą niedrukowaną monografię tej parafii ${ }^{40}$. Ukazały się one pod dziesięcioma tytułami według następującej kolejności: Jubileuszowa księga, Poznaj swoja prastara parafie, Wzbudźmy tradycje będzinskie, Rezurekcja w królewskim swobodnem mieście Bandzinie, Księża będzińscy, Kardynat - późniejszy papież w Będzinie, Historia schodów, Z przeszłości Będzina, Dokument Rady Będzińskiej 1598 roku i Ze starych dokumentów będzińskich.

${ }^{35}$ [T. Jankowski], Historia opłatka, „Dodatek Parafialny” [Sosnowiec], 1 (1934) nr 44, s. 1; 3 (1936) nr 48, s. 2.

${ }^{36}$ Tenże, Naród polski $w$ hołdzie NMP Niepokalanej, „Dodatek Parafialny” [Sosnowiec], 3 (1936) nr 49, s. 1-2; 5 (1938) nr 49, s. 1-2.

${ }^{37}$ Tenże, Majowe nabożeństwo, „Dodatek Parafialny” [Sosnowiec], 4 (1937) nr 19, s. 2.

${ }^{38}$ Archiwum Kurii Metropolitalnej w Częstochowie, sygn. 150/237; J. Związek, Ks. Stasiński Leon (1903-1983), „Częstochowskie Wiadomości Diecezjalne”, 58 (1984) nr 4, s. 95-97; Parafia pw. świętego Antoniego z Padwy w Częstochowie 1936-2016, oprac. S. Kubik, T. Chrzęstek, Częstochowa 2016, s. 24.

${ }^{39}$ Trąba, Życie religijne w Będzinie, s. 448.

${ }^{40}$ J. Kurek, Życie religijne, obyczajowe i kulturalne, w: Będzin 1358-2008, t. 3, s. 275; E Konopczyńska-Tota, Przedmowa, w: L. Stasiński, Będzin - pierwsze dni wojny 1939 r, red. A. Szydłowski, Będzin 2014, s. 3. 
Pierwsza z wymienionych prac, składająca się z pięciu odcinków, zawierała wypisy nazwisk z miejscowej księgi metrykalnej, prowadzonej w latach 1636$1700^{41}$. Jak sam autor później wspominał: „Podanie nazwisk ze starych aktów spotkało się z wielkim zainteresowaniem i życzliwością ze strony mieszkańców będzińskich" "42. Zachęcony tym sukcesem napisał kolejne opracowanie historyczne pt. Poznaj swoja prastara parafię. Złożyło się na nie szesnaście odcinków, w których opisał najstarsze dzieje Będzina (zamek i miasto), powstałą tam parafię (kościół parafialny, kościółek cmentarny i cmentarze) oraz należące do niej okoliczne miejscowości (Gzichów, Małobądź, Brzozowica, Sarnów, Preczów, Ksawera, Koszelew i Warpie) $)^{43}$. Praca nad tym dziełem sprawiła mu wiele satysfakcji. Nadmienił później: „Przyznam się, że w miarę jak poznawałem starożytność naszego Będzina, tym więcej go zacząłem kochać i cenić" ${ }^{44}$. W tej sytuacji zajął się dalszą kwerendą, dzięki której wydobył na światło dzienne kolejne fakty z przeszłości miasta. Tak powstała seria dwunastu artykułów, wydana pod wspólnym tytułem: Wzbudźmy tradycje będzińskie. Opisał w niej m.in. dawne cechy rzemieślnicze (czapniczy i szewski) oraz handel miejski ${ }^{45}$. Niezwykły zbieg okoliczności skłonił go do dalszej twórczości historycznej, o czym wspomniał w następujących słowach:

Na imieniny dostałem miłą ozdobę na biurko: symbolicznego kronikarza. Widocznie czytelnikom Ż[ycia] P[arafialnego] są miłe stare dzieje sławetnego Będzina. Ten to właśnie podarunek podsunął mi myśl napisania o dawnej rezurekcji w Będzinie ${ }^{46}$.

Opublikował wówczas artykuł pt. Rezurekcja w królewskim swobodnem mieście Bandzinie, odtwarzający dawny przebieg mszy św. i procesji rezurekcyjnej. Jednakże po bliższym zapoznaniu się z tekstem można stwierdzić, że niektóre jego partie są fikcyjne i stworzone na potrzeby chwili. Niemniej artykuł jest interesujący, ponieważ zawiera wymienionych z nazwiska faktycznych mieszkańców miasta i okolicy oraz uwzględnienia ich status społeczny ${ }^{47}$. Czerpiąc coraz więcej informacji z bogatego zasobu archiwum parafialnego napisał kolejne rozbudowane opracowanie pt. Księża będzińscy. Tym razem w siedmiu odcinkach przedstawił dzieje miejscowego duchowieństwa na przestrzeni XVII-XX w. ${ }^{48}$. Niewątpliwie ważnym odkryciem, jakiego dokonał, było ustalenie, że w drugiej poł. XVI w.

${ }^{41}$ [L. Stasiński], Jubileuszowa księga, „Życie Parafialne”, 3 (1937) nr 14, s. 2; nr 15, s. 2; nr 17, s. 2 ; nr 18 , s. 2 ; nr 19 , s. 2.

${ }^{42}$ Tenże, Poznaj swoja prastara parafię, „Życie Parafialne”, 3 (1937) nr 16, s. 2.

${ }^{43}$ Tamże; nr 17, s. 1-2; nr 18, s. 2; nr 19, s. 1; nr 20, s. 2; nr 21, s. 2; nr 22, s. 2; nr 23, s. 1-2; nr 24, s. $1-2$; nr 25, s. 2 ; nr 26, s. 2 ; nr 27, s. 2; nr 28, s. 2; nr 29, s. 1-2; nr 30, s. 2; nr 31, s. 2.

${ }^{44}$ Tenże, Wzbudźmy tradycje będzińskie, „Życie Parafialne”, 3 (1937) nr 37, s. 1.

${ }^{45}$ Tamże, s. $1-2 ;$ nr 39 , s. 2 ; nr 43, s. 2 ; nr 44, s. 2 ; nr 45 , s. 2 ; nr 46, s. $2 ;$ nr 47, s. 2 ; nr 48, s. 2 ; nr 49, s. 1-2; nr 50, s. 2; 4 (1938) nr 1, s. 2; nr 5, s. 2.

${ }^{46}$ Tenże, Rezurekcja w królewskim swobodnem mieście Bandzinie, „Życie Parafialne”, 4 (1938) nr 16, s. 1.

${ }^{47}$ Tamże, s. 1-2.

${ }^{48}$ Tenże, Księża będzińscy, „Życie Parafialne”, 4 (1938) nr 17, s. 2; nr 18, s. 2; nr 19, s. 2; nr 22, s. $2 ;$ nr 23, s. 2 ; nr 24, s. 2 ; nr 25, s. 2. 
kościół będziński odwiedził kard. Hipolit Aldobrandini, późniejszy papież Klemens VIII. Wydarzenie to opisał w dwuczęściowym artykule zatytułowanym Kardynat - późniejszy papież w Będzinie ${ }^{49}$. Następnie, po przebadaniu miejscowych protokołów cechowych, doszedł do wniosku, że znajduje się w nich ciekawy materiał do kolejnego tekstu historycznego, w wyniku czego powstała praca pt. Historia schodów, przedstawiająca perypetie towarzyszące budowie żelaznych schodów w kościele ${ }^{50}$. Zainteresowanie lokalną historią pchnęło go w końcu do szukania nowych ustaleń na drodze wywiadów z najstarszymi mieszkańcami Będzina. Dzięki temu napisał cykl artykułów, któremu nadał tytuł: $Z$ przeszłości Będzina. Znalazły się tutaj opisy: kościoła, miasta, ubiorów, potraw, ślubów, wesel, chrzcin i pogrzebów. Niektóre wiadomości sięgały nawet $1864 \mathrm{r}^{51}$. Ostatnie jego dzieła miały niemal charakter edytorski. W takiej formie wydał odpis z miejscowej księgi radzieckiej pod wymownym tytułem Dokument Rady Będzińskiej 1598 roku $u^{52}$. Następnie w publikacji pt. Ze starych dokumentów będzińskich zamieścił jeszcze 9 dokumentów z lat 1621-1835, przy czym niektóre z nich były przytoczone w całości, a inne w części. Ze względu na czytelników zdobył się nawet na przetłumaczenie kilku dokumentów z języka łacińskiego. $Z$ racji, że całość tej publikacji liczyła szesnaście odcinków, toteż niektórym z nich nadał formę opracowań, opisując w ten sposób dawną działalność Rady Miasta, zabudowania plebańskie i folwarczne, grunty kościelne, fundacje kościoła, uposażenia Bractwa Różańcowego oraz spór o prebendę. Wszystko to dopełnił rzetelnie opracowanym biogramem ks. Wawrzyńca Hachulskiego, proboszcza będzińskiego w latach $1800-1838^{53}$.

Całość bloku o tematyce kościelnej zamknęło 7 prac z zakresu biografistyki. Autorami ich byli następujący księża: Teofil Jankowski, Władysław Mach, Stefan Niedźwiedzki i Leon Stasiński. Pierwszy z nich - wspominany już wyżej - zamieścił w latach 1935-1936 na łamach sosnowieckiego „Dodatku Parafialnego” najpierw trzy biogramy, ukazujące życie i działalność osób świętych (św. Stanisława Kostki, św. Cecylii i św. Sylwestra), a następnie opisał bohaterską postawę ks. Ignacego Skorupki, polskiego kapelana wojskowego, który wsławił się w bitwie warszawskiej w $1920 \mathrm{r}$. Wszystkie te opracowania, co warto podkreślić, powstały z okazji przeżywanych wspomnień liturgicznych i rocznic ${ }^{54}$. Drugim autorem był ks. Władysław Mach (ur. 1894 r.), proboszcz w Sosnowcu na Starym Sielcu, a tak-

${ }^{49}$ Tenże, Kardynat - późniejszy papież w Będzinie, ,Życie Parafialne”, 4 (1938) nr 35, s. 2; nr 37, s. 2.

${ }^{50}$ Tenże, Historia schodów, „Życie Parafialne”, 4 (1938) nr 38, s. 2.

${ }^{51}$ Tenże, Z przeszłości Będzina, „Życie Parafialne”, 4 (1938) nr 39, s. 1-2; nr 40, s. 1-2; nr 42, s. $1-2 ; \mathrm{nr} 43$, s. $2 ; \mathrm{nr} 45$, s. 2.

${ }_{52}$ Tenże, Dokument Rady Będzińskiej 1598 roku, „Życie Parafialne”, 5 (1939) nr 2, s. 1-2.

${ }_{53}$ Tenże, Ze starych dokumentów będzińskich, „Życie Parafialne”, 5 (1939) nr 5, s. 1-2; nr 6, s. $1-2 ; \mathrm{nr} 7$, s. 2 ; nr 8 , s. 2 ; nr 9, s. 2 ; nr 10 , s. 2 ; nr 11, s. $1-2 ;$ nr 13, s. $1 ;$ nr 14 , s. 2 ; nr 15, s. 2 ; nr 16, s. $2 ;$ nr 17, s. $2 ;$ nr 18, s. 2; nr 19, s. 2; nr 20, s. 2; nr 22, s. 2.

${ }^{54}$ [T. Jankowski], Św. Stanisław Kostka, „Dodatek Parafialny” [Sosnowiec], 2 (1935) nr 46, s. 1-2; tenże, Św. Cecylia, „Dodatek Parafialny” [Sosnowiec], 2 (1935) nr 47, s. 1-2; tenże, Wieczór Św. Sylwestra, „Dodatek Parafialny” [Sosnowiec], 2 (1935) nr 52, s. 3; tenże, W pamiętna rocznice 
że założyciel i redaktor miejscowych „Wiadomości Parafialnych”55. W czasopiśmie tym opublikował w 1936 r. artykuł o św. Franciszku z Asyżu, pisząc m.in.:

Skreśliłem krótko życiorys i dzieje zakonu św. Franciszka. Jak był wielkim reformatorem w wiekach średnich, że przemienił serca i dusze współczesnego sobie społeczeństwa, tak po tylu już wiekach duch jego żyje nie tylko w klasztorach, ale i pośród ludzi świeckich i w dalszym ciągu w świecie ${ }^{56}$.

O ile do tej pory twórczość autorów była skoncentrowana wokół znanych powszechnie postaci z życia Kościoła katolickiego, to kolejne już biogramy miały zdecydowanie wymiar regionalny i dotyczyły zmarłych duchownych z Zagłębia Dąbrowskiego. W takim nurcie można sklasyfikować dwa ostatnie opracowania, które wyszły spod piór ks. Stefana Niedźwiedzkiego i ks. Leona Stasińskiego, znanych z prezentowanych wyżej publikacji historycznych. Tym razem utrwalili oni na łamach dąbrowskiego „Dodatku Parafialnego” i będzińskiego „Życia Parafialnego" wybitne zasługi lokalnych duszpasterzy: ks. Stanisława Mazurkiewicza z Dąbrowy Górniczej (zmarłego w 1933 r.) i ks. Tadeusza Peche z Będzina (zmarłego w 1937 r.), których nawiasem mówiąc osobiście znali ${ }^{57}$.

Choć zagadnienia kościelne zdecydowanie dominowały w zamieszczonym powyżej wykazie publikacji historycznych, to jednak nie brakowało i takich, które odnosiły się do spraw pozakościelnych. Wyzwanie to podjęli ks. Tadeusz Peche i ks. Teofil Jankowski, wydając drukiem osobne artykuły, zatytułowane: Historia kredytu bezprocentowego i W rocznice Cudu nad Wista. Pierwsza z wymienionych prac ukazała się na łamach „Życia Parafialnego” w 1936 r. i dotyczyła kwestii społecznych. Druga natomiast została opublikowana w sosnowieckim „Dodatku Parafialnym" w 1937 r., mając ewidentnie wydźwięk patriotyczny ${ }^{58}$.

\section{Zakończenie}

W diecezji częstochowskiej w okresie II Rzeczypospolitej posługiwało 473 księży. Niektórzy z nich, poza działalnością duszpasterską, zajmowali się także twórczością pisarską, publikując swoje teksty m.in. na łamach pism diecezjalnych: „Niedzieli” (od 1926 r.), „Młodzieży Katolickiej” (od 1926 r.) i „Kalendarza Jasnogórskiego" (od 1928 r.). Ze względu, iż czasopisma te miały swój charakterystyczny profil, a przy tym również stałych współpracowników, toteż wielu duchownych w diecezji nie decydowało się rozwijać talentu pisarskiego. Zmieniło się to wyraźnie od 1928 r., kiedy na rynku wydawniczym pojawiła się

bohaterskiej śmierci ks. Ignacego Skorupki, „Dodatek Parafialny” [Sosnowiec], 3 (1936) nr 32, s. $1-2$.

${ }^{55}$ AACz, sygn. AP 112; J. Przemsza-Zieliński, Sosnowiecka encyklopedia historyczna. Sygnaty biograficzno-tematyczne, z. 3, Sosnowiec 1996, s. 283; M. Trąba, Proboszczowie parafii św. Barbary, w: Parafia św. Barbary w Sosnowcu 1908-2008, red. M. Trąba, Katowice 2008, s. 54-55.

${ }^{56}$ [W. Mach], Św. Franciszek z Asyżu, „Wiadomości Parafialne” [Stary Sielec], 3 (1936) nr 36, s. 2.

${ }^{57}$ [S. Niedźwiedzki], Życiorys śp. ks. prałata Stanisława Mazurkiewicza, „Dodatek Parafialny” [Dąbrowa Górnicza], 2 (1935) nr 62, s. 1; L. S[tasiński], Ks. Tadeusz Peche. Proboszcz parafii Będzin, „Życie Parafialne”, 3 (1937) nr 32, s. 1-2.

${ }^{58}$ T. Peche, Historia kredytu bezprocentowego, „Życie Parafialne”, 2 (1936) nr 33, s. 2; T. J[ankowski], W rocznicę Cudu nad Wista, „Dodatek Parafialny” [Sosnowiec], 4 (1937) nr 33, s. 1-2. 
prasa parafialna. Jej rozwój sprawił, że do 1939 r. w diecezji częstochowskiej były wydawane zarówno czasopisma ponadparafialne („Częstochowskie Wiadomości Parafialne” i „Wiadomości Parafialne” [Sosnowiec - Pogoń, Stary Sielec, Nowy Sielec]), jak i czasopisma parafialne („Kronika Parafialna”, „Wiadomości Parafialne” [Bobrowniki], „Głos Parafialny”, „Wiadomości Parafialne” [Sosnowiec - Nowy Sielec] „Głos Duszpasterza”/,Dodatek Parafialny”, „Dodatek Parafialny” [Sosnowiec], „Wiadomości Parafialne” [Sosnowiec - Stary Sielec], „Wiadomości Parafialne” [Strzemieszyce], „Życie Parafialne” i „Wiadomości Parafialne" [Zagórze]). W tych okolicznościach wielu księży zajęło się twórczością pisarską, dzieląc się swoimi przemyśleniami i ustaleniami z czytelnikami. Wśród publikowanych na łamach prasy parafialnej artykułów znalazło się co najmniej 26 prac o tematyce historycznej. Umownie można przyjąć, że dotyczyły one zagadnień kościelnych (24 opracowania) i pozakościelnych ( 2 opracowania). Autorami ich byli następujący księża: Teofil Jankowski (10 artykułów), Władysław Mach (1 artykuł), Stefan Niedźwiedzki (2 artykuły), Tadeusz Peche (2 artykuły) i Leon Stasiński (11 artykułów). Pod względem warsztatowym najwyższą jakość prezentowały prace ks. L. Stasińskiego, pisane przeważnie w odcinkach i na podstawie źródeł archiwalnych. Gdyby je wszystkie zsumować, to trzeba przyjąć, że ogółem zamieścił on aż 67 publikacji. Pełne zestawienie bibliograficzne wszystkich prac historycznych, które zostały wydane drukiem przez księży diecezji częstochowskiej na łamach czasopism parafialnych do 1939 r., zawiera dołączony do niniejszego artykułu aneks.

\section{ANEKS}

\section{Bibliografia duchowieństwa diecezji częstochowskiej. Publikacje historyczne na lamach prasy parafialnej w latach 1925-1939}

[Jankowski T.], Historia opłatka, „Dodatek Parafialny” [Sosnowiec], 1 (1934) nr 44, s. 1; [Jankowski T.], Historia oplatka, „Dodatek Parafialny” [Sosnowiec], 3 (1936) nr 48, s. 2; J[ankowski] T., Majowe nabożeństwo, „Dodatek Parafialny” [Sosnowiec], 4 (1937) nr 19, s. 2;

J[ankowski] T., Naród polski w hołdzie NMP Niepokalanej, „Dodatek Parafialny” [Sosnowiec], 3 (1936) $\mathrm{nr}$ 49, s. 1-2;

J[ankowski] T., Naród polski w hołdzie NMP Niepokalanej, ,Dodatek Parafialny” [Sosnowiec], 5 (1938) nr 49, s. 1-2;

[Jankowski T.], Św. Cecylia, „Dodatek Parafialny” [Sosnowiec] 2 (1935) nr 47, s. 1-2;

[Jankowski T.], Św. Stanistaw Kostka, „Dodatek Parafialny” [Sosnowiec] 2 (1935) nr 46, s. 1-2;

J[ankowski] T., W pamiętna rocznicę bohaterskiej śmierci ks. Ignacego Skorupki, „Dodatek Parafialny" [Sosnowiec], 3 (1936) nr 32, s. 1-2;

J[ankowski] T., W rocznicę Cudu nad Wista, „Dodatek Parafialny” [Sosnowiec], 4 (1937) nr 33, s. 1-2;

J[ankowski] T., Wieczór Św. Sylwestra, „Dodatek Parafialny” [Sosnowiec] 2 (1935) nr 52, s. 3;

[Mach W.], Św. Franciszek z Asyżu, „Wiadomości Parafialne” [Stary Sielec], 3 (1936) nr 36, s. 2;

[Niedźwiedzki S.], Co to jest parafia?, „Głos Duszpasterza” 1 (1934) nr 20, s. 1-2; 
[Niedźwiedzki S.], Życiorys śp. ks. prałata Stanisława Mazurkiewicza, „Dodatek Parafialny" [Dąbrowa Górnicza] 2 (1935) nr 62, s. 1;

[Peche T.], Czym jest diecezja?, „Życie Parafialne”, 2 (1936) nr 4, s. 1-2;

Peche T., Historia kredytu bezprocentowego, „Życie Parafialne” 2 (1936) nr 33, s. 2;

[Stasiński 1.], Dokument Rady Będzińskiej 1598 roku, „Życie Parafialne”, 5 (1939) nr 2, s. 1-2;

S[tasiński] L., Historia schodów, „Życie Parafialne”, 4 (1938) nr 38, s. 2;

[Stasiński L.], Jubileuszowa księga, ,Życie Parafialne”, 3 (1937) nr 14, s. 2; nr 15, s. 2; nr 17 , s. 2 ; nr 18 , s. 2 ; nr 19 , s. 2 ;

S[tasiński] L., Kardynat - późniejszy papież w Będzinie, „Życie Parafialne”, 4 (1938) nr 35 , s. 2 ; nr 37, s. 2 ;

S[tasiński] L., Ks. Tadeusz Peche. Proboszcz parafii Będzin, „Życie Parafialne”, 3 (1937) nr 32, s. 1-2;

S[tasiński] L., Księża będzińscy, „Życie Parafialne”, 4 (1938) nr 17, s. 2; nr 18, s. 2; nr 19, s. $2 ; \operatorname{nr} 22$, s. 2 ; nr 23, s. $2 ;$ nr 24, s. 2 ; nr 25, s. 2 ;

[Stasiński L.], Poznaj swoja prastara parafię, „Życie Parafialne” 3 (1937) nr 16, s. 2; nr 17 , s. $1-2 ;$ nr 18 , s. 2 ; nr 19 , s. 1 ; nr 20 , s. 2 ; nr 21 , s. 2 ; nr 22, s. 2 ; nr 23 , s. $1-2 ;$ nr 24 , s. $1-2 ;$ nr 25 , s. $2 ;$ nr 26 , s. 2 ; nr 27, s. 2 ; nr 28, s. 2 ; nr 29, s. $1-2 ;$ nr 30, s. 2 ; nr 31, s. 2 ;

S[tasiński] L., Rezurekcja $w$ królewskim swobodnem mieście Bandzinie, „Życie Parafialne" 4 (1938) nr 16, s. 1-2;

S[tasiński] L., Wzbudźmy tradycje będzińskie, „Życie Parafialne”, 3 (1937) nr 37, s. 1-2; nr 39, s. 2 ; nr 43, s. 2 ; nr 44, s. 2 ; nr 45, s. 2 ; nr 46, s. 2 ; nr 47, s. 2 ; nr 48, s. 2 ; nr 49, s. $1-2 ;$ nr 50, s. $2 ; 4$ (1938) nr 1, s. 2; nr 5, s. 2;

S[tasiński] L., Z przeszłości Będzina, „Życie Parafialne”, 4 (1938) nr 39, s. 1-2; nr 40, s. $1-2$; nr 42, s. $1-2$; nr 43, s. 2 ; nr 45, s. 2;

Stasiński L., Ze starych dokumentów będzińskich, „Życie Parafialne”, 5 (1939) nr 5, s. 1-2; nr 6 , s. $1-2 ;$ nr 7 , s. 2 ; nr 8 , s. 2 ; nr 9, s. 2 ; nr 10 , s. 2 ; nr 11, s. $1-2 ;$ nr 13 , s. $1 ;$ nr 14 , s. $2 ;$ nr 15 , s. $2 ;$ nr 16 , s. 2 ; nr 17, s. $2 ;$ nr 18, s. $2 ;$ nr 19, s. 2 ; nr 20, s. 2 ; nr 22, s. 2.

\section{BIBLIOGRAFIA}

\section{Źródła}

Archiwalne

Archiwum Archidiecezji Częstochowskiej im. ks. Walentego Patykiewicza w Częstochowie $(\mathrm{AACz})$

sygn. AP 68, AP 112, AP 119, AP 157, AP 331.

Archiwum Kurii Metropolitalnej w Częstochowie (AKMCz)

sygn. $150 / 237$.

Archiwum Parafii Najświętszej Maryi Panny w Sosnowcu-Kazimierzu

sygn. brak, Kronika parafii.

Drukowane

Katalog kościołów i duchowieństwa diecezji częstochowskiej 1939, Częstochowa 1939.

Pius XI, Ditionis Polonicae de nova dioecesium latini ritus circumscriptione "Vixdum Poloniae unistas», „Acta Apostolicae Sedis”, 17 (1925), s. 521-528.

Stanko Przemysław, Bulla «Vixdum Poloniae unista». Reprodukcje stron oryginału bulli: tekst łaciński - tłumaczenie na język polski, Katowice 2015. 


\section{Opracowania}

Bajor Agnieszka, Tygodnik katolicki „Niedziela” 1926-1939, „Rocznik Historii Prasy Polskiej", 3 (2000) z. 2/6, s. 91-114.

Bajor Agnieszka, Żmigrodzki Zbigniew, Tygodnik katolicki „Niedziela” 1926-1939, Częstochowa 2002.

Bibliografia katolickich czasopism religijnych w Polsce 1918-1944, red. Z. Zieliński, Lublin 1981.

[Jankowski Teofil], Historia opłatka, „Dodatek Parafialny” [Sosnowiec], 1 (1934) nr 44, s. 1.

[Jankowski Teofil], Historia optatka, „Dodatek Parafialny” [Sosnowiec], 3 (1936) nr 48, s. 2.

J[ankowski] T[eofil], Majowe nabożeństwo, „Dodatek Parafialny” [Sosnowiec], 4 (1937) nr 19, s. 2.

J[ankowski] T[eofil], Naród polski w hołdzie NMP Niepokalanej, „Dodatek Parafialny” [Sosnowiec], 3 (1936) nr 49, s. 1-2.

J[ankowski] T[eofil], Naród polski w hołdzie NMP Niepokalanej, „Dodatek Parafialny” [Sosnowiec], 5 (1938) nr 49, s. 1-2.

[Jankowski Teofil], Sw. Cecylia, „Dodatek Parafialny” [Sosnowiec], 2 (1935) nr 47, s. 1-2.

[Jankowski Teofil], Św. Stanistaw Kostka, „Dodatek Parafialny” [Sosnowiec], 2 (1935) nr 46 , s. $1-2$.

J[ankowski] T[eofil], W pamiętnq rocznicę bohaterskiej śmierci ks. Ignacego Skorupki, „Dodatek Parafialny” [Sosnowiec], 3 (1936) nr 32, s. 1-2.

J[ankowski] T[eofil], W rocznice Cudu nad Wista, „Dodatek Parafialny” [Sosnowiec], 4 (1937) nr 33, s. 1-2.

J[ankowski] T[eofil], Wieczór Św. Sylwestra, „Dodatek Parafialny” [Sosnowiec], 2 (1935) nr 52, s. 3.

Kapuściński Jacek, Aktywność społeczno-kulturalna duchowieństwa diecezji częstochowskiej (do 1939 r.), w: Ślask - Polska - Europa - Świat. Pamięci Profesora Jana Przewłockiego, red. K. Miroszewski, M. Stolarczyk, Katowice 2013, s. 85-105.

Kapuściński Jacek, Bibliografia duchowieństwa diecezji częstochowskiej. Publikacje na lamach „Kroniki Diecezji Kujawsko-Kaliskiej” w latach 1907-1925, „Studia Włocławskie", 17 (2015), s. 531-538.

Kapuściński Jacek, Charakterystyka strukturalna kadr duchowieństwa diecezji częstochowskiej w latach 1925-1939, „Veritati et Caritati”, 4 (2015), s. 267-304.

Kapuściński Jacek, Publikacje księży diecezji częstochowskiej na łamach „Kalendarza Jasnogórskiego” z lat 1929-1938, „Veritati et Caritati”, 8 (2017), s. 277-296.

Kapuściński Jacek, $Z$ «Niedziela» na co dzień. Formacja społeczno-religijna w latach 1926-1939, „Biuletyn Informacyjny Komisji Historycznej Polskiej Akademii Nauk Oddział Katowice”, 11 (2014), s. 14-15.

Konopczyńska-Tota Ewelina, Przedmowa, w: L. Stasiński, Będzin - pierwsze dni wojny 1939 r., red. A. Szydłowski, Będzin 2014, s. 3-10.

Kośny Grzegorz, Mój umitowany kościót. Monografia kościoła parafialnego pw. Św. Jana Chrzciciela w Brzeźnicy k. Radomska, Brzeźnica-Radomsko 2011.

Kubina Teodor, Arcypasterska zachęta, „Niedziela”, 1 (1926) nr 1, s. 2.

Kurek Jacek, Życie religijne, obyczajowe i kulturalne, w: Będzin 1358-2008, t. 3, red. A. Glimos-Nadgórska, Będzin 2008, s. 271-341.

[Mach Władysław], Św. Franciszek z Asyżu, „Wiadomości Parafialne” [Stary Sielec], 3 (1936) nr 36, s. 2. 
Malarski Tadeusz, Franusiak Kazimierz, Mandrysz Iwo, Dzieje parafii św. Józefa - Częstochowa-Raków, Częstochowa [b.r.w.].

Marcinkowski Władysław, Historia parafji Przedmość, Częstochowa 1928.

Mielczarek Tomasz, Od „Monitora” do „Gońca Reklamowego”. Dzieje prasy częstochowskiej (1769-1994), Kielce 1996.

[Niedźwiedzki Stefan], Co to jest parafia?, „Głos Duszpasterza”, 1 (1934) nr 20, s. 1-2.

[Niedźwiedzki Stefan], Życiorys śp. ks. prałata Stanisława Mazurkiewicza, „,Dodatek Parafialny" [Dąbrowa Górnicza], 2 (1935) nr 62, s. 1.

Nowe pismo parafialne w naszej diecezji, „Niedziela”, 10 (1935) nr 47, s. 568.

Nowe pismo parafialne, „Niedziela”, 9 (1934) nr 3, s. 34;

P[atykiewicz] W[alenty], Ks. Tadeusz Peche (1882-1937), „Częstochowskie Wiadomości Diecezjalne", 38 (1964) nr 7, s. 169.

Parafia pw. świętego Antoniego z Padwy w Częstochowie 1936-2016, oprac. S. Kubik, T. Chrzęstek, Częstochowa 2016.

[Peche Tadeusz], Czym jest diecezja?, „Życie Parafialne”, 2 (1936) nr 4, s. 1-2.

Peche Tadeusz, Historia kredytu bezprocentowego, „Życie Parafialne”, 2 (1936) nr 33, s. 2.

Pierwsze pismo parafialne w diecezji częstochowskiej, „Niedziela”, 4 (1929) nr 14, s. 171.

Przemsza-Zieliński Jan, Sosnowiecka encyklopedia historyczna. Sygnały biograficzno-tematyczne, z. 3, Sosnowiec 1996;

Sętowski Juliusz, Cmentarz Kule w Częstochowie. Przewodnik biograficzny, Częstochowa 2005.

Snoch Bogdan, Mała encyklopedia Częstochowy, Częstochowa 2002.

Stanko Przemysław, Bulla «Vixdum Poloniae unista» z 28 października 1925 roku. Gene$z a$-znaczenie - dzieje - edycja, Katowice 2015.

[Stasiński Leon], Dokument Rady Będzińskiej 1598 roku, „Życie Parafialne”, 5 (1939) nr 2, s. 1-2.

S[tasiński] L[eon], Historia schodów, ,Życie Parafialne”, 4 (1938) nr 38, s. 2.

[Stasiński Leon], Jubileuszowa księga, „Życie Parafialne”, 3 (1937) nr 14, s. 2; nr 15, s. 2; nr 17 , s. 2 ; nr 18 , s. 2 ; nr 19, s. 2.

S[tasiński] L[eon], Kardynat - późniejszy papież w Będzinie, „Życie Parafialne”, 4 (1938) nr 35, s. 2; nr 37, s. 2.

S[tasiński] L[eon], Ks. Tadeusz Peche. Proboszcz parafii Będzin, „Życie Parafialne”, 3 (1937) nr 32, s. 1-2.

S[tasiński] L[eon], Księża będzińscy, „Życie Parafialne”, 4 (1938) nr 17, s. 2; nr 18, s. 2; nr 19, s. 2 ; nr 22, s. 2 ; nr 23, s. 2 ; nr 24, s. 2 ; nr 25, s. 2.

[Stasiński Leon], Poznaj swoja prastara parafię, „Życie Parafialne”, 3 (1937) nr 16, s. 2; nr 17, s. $1-2$; nr 18, s. 2 ; nr 19, s. 1 ; nr 20, s. 2 ; nr 21, s. 2 ; nr 22, s. 2; nr 23, s. 1-2; nr 24 , s. $1-2$; nr 25 , s. 2 ; nr 26 , s. 2 ; nr 27 , s. 2 ; nr 28 , s. 2 ; nr 29 , s. $1-2$; nr 30 , s. 2 ; nr 31, s. 2.

S[tasiński] L[eon], Rezurekcja w królewskim swobodnem mieście Bandzinie, „Życie Parafialne", 4 (1938) nr 16, s. 1-2.

S[tasiński] L[eon], Wzbudźmy tradycje będzińskie, „Życie Parafialne”, 3 (1937) nr 37, s. $1-2 ;$ nr 39 , s. 2 ; nr 43, s. 2 ; nr 44, s. 2 ; nr 45, s. 2 ; nr 46, s. 2; nr 47, s. 2; nr 48, s. 2; nr 49, s. $1-2 ;$ nr 50, s. $2 ; 4(1938)$ nr 1 , s. $2 ;$ nr 5 , s. 2.

S[tasiński] L[eon], Z przeszłości Będzina, „Życie Parafialne”, 4 (1938) nr 39, s. 1-2; nr 40, s. $1-2 ;$ nr 42 , s. $1-2 ;$ nr 43 , s. 2 ; nr 45, s. 2.

Stasiński Leon, Ze starych dokumentów będzińskich, „Życie Parafialne”, 5 (1939) nr 5, s. $1-2$; nr 6 , s. $1-2$; nr 7, s. 2 ; nr 8 , s. 2 ; nr 9, s. 2 ; nr 10, s. 2; nr 11, s. 1-2; nr 13, s. 1; nr 14 , s. 2 ; nr 15 , s. 2 ; nr 16 , s. 2 ; nr 17 , s. 2 ; nr 18 , s. 2 ; nr 19 , s. 2 ; nr 20 , s. 2 ; nr 22 , 
s. 2.

Trąba Mariusz, Proboszczowie parafii św. Barbary, w: Parafia św. Barbary w Sosnowcu 1908-2008, red. M. Traba, Katowice 2008, s. 49-61.

Trąba Mariusz, Życie religijne w Będzinie (1918-1939), w: Będzin 1358-2008, t. 3, red. A. Glimos-Nadgórska, Będzin 2008, s. 423-452.

Walicki Jan, Ks. Józef Krzyżanowski, „Częstochowskie Wiadomości Diecezjalne”, 24-31 (1957) nr 3, s. 124.

Walicki Jan, Śp. ks. Stefan Niedźwiedzki, „Częstochowskie Wiadomości Diecezjalne”, 34 (1960) nr 3, s. 114-116.

Wlaźlak Władysław Piotr, Ks. Teofil Jankowski (28 II 1877-11 IV 1951), „Wiadomości Archidiecezji Częstochowskiej”, 80 (2006) nr 12, s. 74-75.

Związek Jan, Dzieje diecezji częstochowskiej w okresie II Rzeczypospolitej, Częstochowa 1990.

Związek Jan, Ks. Stasiński Leon (1903-1983), „Częstochowskie Wiadomości Diecezjalne", 58 (1984) nr 4, s. 95-97.

Związek Jan, Kuraś Stanisław (1887-1974), w: Słownik polskich teologów katolickich, t. 6, red. L. Grzebień, Warszawa 1983, s. 273-274.

Związek Jan, Martyrologium kapłanów diecezji częstochowskiej w czasie II wojny światowej, „Częstochowskie Studia Teologiczne”, 4 (1976) s. 185-300.

\title{
HISTORIOGRAPHICAL ACHIEVEMENTS OF CZESTOCHOWA DIOCESE PRIESTS IN THE PARISH PRESS IN 1925-1939
}

\begin{abstract}
Summary
The goal of the article is to discuss historical works written in 1925-1939 by clergymen of Czestochowa diocese in the parish magazines. To the end of August 1939 in diocese there were 12 such magazines, published in Bedzin, Bobrowniki, Częstochowa, Dąbrowa Górnicza, Nowy Sielc, Porąbka, Sosnowiec, Stary Sielc, Strzemieszyce and Zagórz. Generally there were 26 published works of this type, which considered ecclesial and outside of church issues. The authors were the following priests: Teofil Jankowski (10 articles), Władysław Mach (1 article), Stefan Niedźwiedzki (2 articles), Tadeusz Peche (2 articles) i Leon Stasiński (11 articles). The high craft was presented the last of mentioned authors, whose works are still current.
\end{abstract}

Key words: parish magazine; Częstochowa diocese; clergy; parish; publication 